\title{
Herpes zoster lumbar radiculitis
}

Abhinav R. Changa, MD, and Rajan Jain, MD

Neurolog ${ }^{\circledR}$ 2020;95:552-553. doi:10.1212/WNL.0000000000010586

Figure 1 Photographs of the patient's right leg

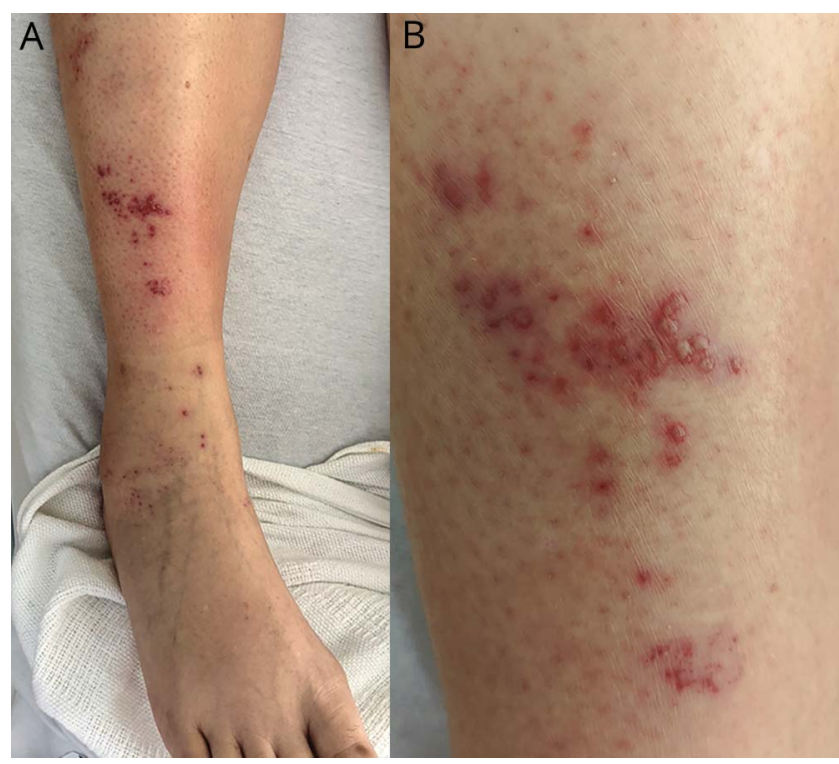

(A, B) Typical zoster vesicles on the right shin in L5 dermatomal distribution.

\section{Correspondence}

Dr. Changa

Abhinavchanga@gmail.com

A 55-year-old immunocompetent woman with a history of shingles presented with 1 week of sharp pain in the right leg, associated with weakness, fevers, and vesicular eruptions. Skin examination showed grouped vesicles distributed predominantly along the right L5 dermatome (figure 1). Neurologic examination revealed right leg weakness ( $3 / 5$ knee flexion, $4 / 5$ knee extension, $3 / 5$ dorsiflexion, $1 / 5$ toe extension), absent right ankle jerk, and decreased sensation in the anterior shin. ${ }^{1}$ Postcontrast lumbosacral plexus MRI demonstrated right L5 extraforaminal nerve root thickening and enhancement, consistent with radiculitis (figure 2). ${ }^{2}$ Skin DNA-PCR testing confirmed herpes zoster. Treatment with IV acyclovir and gabapentin resulted in symptomatic improvement.

\section{Study funding}

No targeted funding reported.

\section{Disclosure}

The authors report no disclosures relevant to this manuscript. Go to Neurology.org/ $\mathrm{N}$ for full disclosures. 
Figure 2 Postcontrast T1-weighted fat-saturated MRI of the lumbosacral plexus

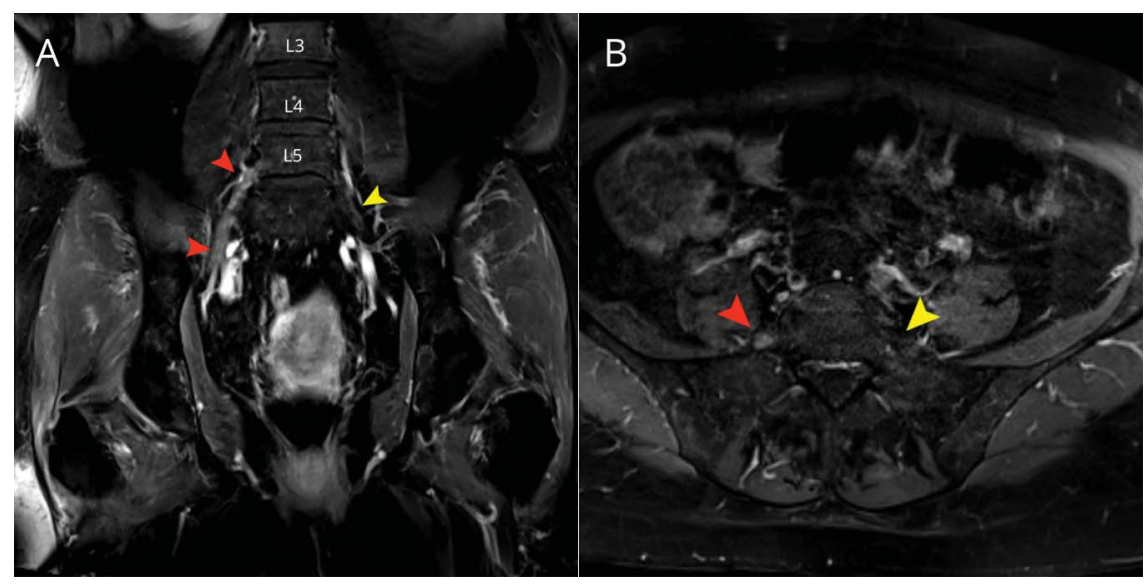

(A) Coronal and (B) axial views show enhancement and thickening of the extraforaminal right L5 nerve root (red arrowheads) and a normal left L5 nerve root (yellow arrowheads).

\begin{tabular}{|c|c|c|}
\hline Name & Location & Contribution \\
\hline $\begin{array}{l}\text { Abhinav } \\
\text { R. } \\
\text { Changa, } \\
\text { MD }\end{array}$ & $\begin{array}{l}\text { New York University } \\
\text { Langone Medical } \\
\text { Center, New York }\end{array}$ & $\begin{array}{l}\text { Acquisition, analysis, and } \\
\text { interpretation of data for the } \\
\text { work; treating physician; } \\
\text { drafting of the manuscript and } \\
\text { revising it critically; final } \\
\text { approval of the version to be } \\
\text { published }\end{array}$ \\
\hline $\begin{array}{l}\text { Rajan } \\
\text { Jain, MD }\end{array}$ & $\begin{array}{l}\text { New York University } \\
\text { Langone Medical } \\
\text { Center, New York }\end{array}$ & $\begin{array}{l}\text { Conceptualization and designing } \\
\text { of the work; evaluation of } \\
\text { imaging; acquisition, analysis, } \\
\text { and interpretation of data for } \\
\text { the work; drafting of the } \\
\text { manuscript and revising it } \\
\text { critically; final approval of the } \\
\text { version to be published }\end{array}$ \\
\hline
\end{tabular}

\section{References}

1. Thomas JE, Howard FM Jr. Segmental zoster paresis: a disease profile. Neurology 1972;22:459-466.

2. Hanakawa T, Hashimoto S, Kawamura J, Nakamura M, Suenaga T, Matsuo M. Magnetic resonance imaging in a patient with segmental zoster paresis. Neurology 1997;49:631-632.

\section{Announcing... \\ Child Neurology: A Case-Based Approach Cases from the Neurology ${ }^{\circ}$ Resident \& Fellow Section}

This collaboration between the American Academy of Neurology (AAN) and the Child Neurology Society (CNS) represents a collection of reprinted cases from the past 15 years from the Neurology Resident \& Fellow Section.

An invaluable resource for both adult and pediatric neurologists and trainees! FREE download: NPub.org/cnbook 


\title{
Neurology
}

\author{
Herpes zoster lumbar radiculitis \\ Abhinav R. Changa and Rajan Jain \\ Neurology 2020;95;552-553 Published Online before print August 5, 2020 \\ DOI 10.1212/WNL.0000000000010586
}

This information is current as of August 5, 2020

$\begin{array}{ll}\begin{array}{l}\text { Updated Information \& } \\ \text { Services }\end{array} & \begin{array}{l}\text { including high resolution figures, can be found at: } \\ \text { http://n.neurology.org/content/95/12/552.full }\end{array} \\ \text { References } & \text { This article cites } 2 \text { articles, } 2 \text { of which you can access for free at: } \\ \text { http://n.neurology.org/content/95/12/552.full\#ref-list-1 } & \text { This article, along with others on similar topics, appears in the } \\ \text { following collection(s): } & \text { Clinical neurology examination } \\ \text { http://n.neurology.org/cgi/collection/clinical_neurology_examination } & \text { MRI } \\ \text { http://n.neurology.org/cgi/collection/mri } & \text { Peripheral neuropathy } \\ & \text { http://n.neurology.org/cgi/collection/peripheral_neuropathy } \\ & \text { Information about reproducing this article in parts (figures,tables) or in } \\ & \text { its entirety can be found online at: } \\ & \text { http://www.neurology.org/about/about_the_journal\#permissions } \\ \text { Permissions \& Licensing } & \text { Information about ordering reprints can be found online: } \\ & \text { http://n.neurology.org/subscribers/advertise }\end{array}$

Neurology ${ }^{\circledR}$ is the official journal of the American Academy of Neurology. Published continuously since 1951, it is now a weekly with 48 issues per year. Copyright @ 2020 American Academy of Neurology. All rights reserved. Print ISSN: 0028-3878. Online ISSN: 1526-632X.

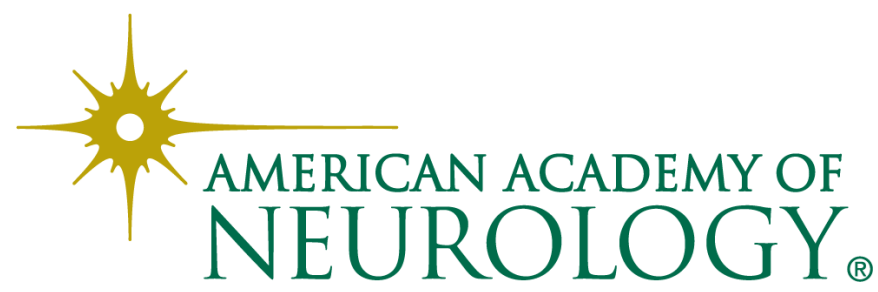

